\title{
ATELLÊE \\ http://www.revistas.ufg.br/index.php/atelie \\ Changing work and the global commodification of ethanol
}

\author{
Mudanças no trabalho e a \\ mercantilização global de etanol \\ Le changement au travail et la \\ marchandisation d'ethanol
}

\author{
Brian Garvey \\ University of Strathclyde \\ brian.garvey@strath.ac.uk
}

Maria Joseli Barreto

Universidade Estadual Paulista Júlio de Mesquita Filho

joselibarreto5@yahoo.com.br

\begin{abstract}
Leading firms in energy and transport production seek to make ethanol a 'global commodity' and stretch their operations across spatial boundaries. This paper is concerned with the consequent change to work availability and quality in the sugar and ethanol industry in the west of Sao Paulo state. David Harvey's concept of the spatial fix helps to link foreign investment of Brazil's sugar and ethanol sector to emerging biofuel markets in Europe and the 2008 financial crisis, and explain implications for work creation and destruction. The testimonies of workers cutting and transporting sugar cane, those operating or maintaining machinery inside the new mills and former cane cutters that have joined the landless movements point to paradoxical changes to work quality and precarity and lead us to question corporate claims of social responsibility. The land and wealth concentration by leading firms expanding into the territories of Mato Grosso do Sul and Goias bring fresh challenges to the collective organisations of labour and the landless.
\end{abstract}

Keywords: commodification,ethanol, work, territory

\section{Resumo}

A medida que companhias líderes de Mercado na produção e transporte de energia procuram fazer do etanol um produto global (global commodity) e assim expandir as suas operações além fronteiras, este artigo explora questões relativas as modificações da disponibilidade de trabalho, assim como a padrões de qualidade na indústria de açúcar e etanol no oeste do estado de Sao Paulo. A noção de spatial fix desenvolvida 
por David Harvey ajuda a interligar os investimentos estrangeiros no sector de açúcar e etanol no Brasil, com os mercados emergentes de biocombustiveis na Europa, assim como com a crise financeira de 2008, explicando assim repercussões na criação e destruição de trabalho. Os depoimentos de trabalhadores que cortam e transportam cana de açúcar, que operam e fazem a manutenção de máquinas dentro das novas usinas, e de ex-cortadores de cana que se juntaram aos movimentos sem terra, indicam mudanças paradoxais na qualidade e precariedade do trabalho, levando-nos a questionar as pretensões corporativas relativas à responsabilidade social. A concentração da terra e da riqueza por empresas líderes em expansão nos territórios de Mato Grosso do Sul e Goiás trazem novos desafios para as organizações coletivas de trabalho e para os sem-terra.

Palavras-chave: mercantilização, etanol, trabalho, território

\begin{abstract}
Resumé
Pendant que les entreprises éminentes d'énergie et de transport promeuvent l'éthanol en tant que 'marchandise globale' et se répandent à travers des frontières spatiales, cette intervention se focalise sur le changement qui en résulte dans la disponibilité et la qualité du travail dans l'industrie d'éthanol et de sucre dans l'ouest de l'état de Sao Paulo. Le concept de la 'spatial fix/réparation spatiale' de David Harvey aide à lier l'investissement étranger dans le sucre et l'éthanol brésilien aux marchés émergents de biocarburants en Europe et à la crise financière de 2008, et explique les implications pour la création et la destruction du travail. Les témoignages des ouvriers qui coupent et transportent la canne à sucre, ceux qui font marcher ou qui maintiennent les machines dans les nouvelles usines et des anciens ouvriers qui se sont attachés au mouvement des sans-terre indiquent des changements paradoxaux à la qualité et à la précarité du travail et nous mènent à poser des questions sur les prétentions d'entreprises concernant la responsabilité sociale. La concentration de terre et de richesse des entreprises éminentes qui sont en train de s'étendre jusque dans les territoires de Mato Grosso do Sul et Goias apporte de nouveaux défis pour les organismes du travail et des sans-terre.
\end{abstract}

Mots-clés: la marchandisation, l'éthanol, le travail, la terre

\title{
Introduction
}

Biofuels have been presented by corporations, governments and international organisations as triple winners, bringing advances in environmental, economic and social fields. In their view biofuelsnot only reduce carbon emissions in comparison with fossil fuels, but bring technological advances to rural areas, and promote trade, development and income in the global south (BIOFRAC, 2006; UNICA, 2010; IEA, 2011; WTO, 2014). The emergence of the 'green' economy has, for organisations such as United Nations and International Labour Organisation (2012a and b), also led to an aspiration for creating socially committed, 'decent' jobs. As favourable projections for the international biofuel market engender international investment in Brazilian agriculture and an export-orientated promotion of ethanol production by public-private partnerships, this paper 
considers the extent to which related changes in employment, as articulated by workers in the sector, can be considered socially responsible or 'sustainable'.

We present the experiences of four categories of workers in an area of industrial consolidation and one of territorial expansion in western Sao Paulo state; i) agricultural and industrial workers who have lost their jobs as machine operators, mechanics and harvesters as a result of recent closures and mechanisation; ii) salaried and seasonally contracted sugar cane cutters experiencing work intensification as mechanisation replaces manual labour; iii) drivers of outsourced trucks transporting raw sugar cane. These workers have been subject to changes in work security, intensity and precarity as a result of the internationalisation of ethanol as a commodity. As the territorial advances of leading firms are accelerated with the injection of international capital we consider a forth category of worker; iv) those urban and rural dwellers who seek but are unable to reproduce small scale agriculture in the face of competition for land and credit large corporations. Many of these have joined the landless movements in the western state and their testimonies point to further implications of the current prevailing model of production that is extending west and northwards into Brazilian savannas and pastures.

\section{Overview of paper}

We begin by setting out our methodologythat engaged workers within an area of relative industrial concentration (Middle Paranapanema) and of westward expansion (Pontal de Paranapanema) in Sao Paulo state. Through the prism of David Harvey's concept of the spatial fix, we link international biofuel policy to the international investment in Brazilian ethanol production following the financial crisis, and to subsequent changes to land and wealth concentration in the sector. The workers' testimonies are presented to highlight the implications of these transformations for labour security and quality. In light of their experiences we conclude by considering what these mean in relation to the industry's claim to socially responsible employment.

\section{Methodology}

The paper presents research carried out between 2010 and 2013 in the Mid Paranapanema and Pontal of Paranapanema regions to the west of Sao Paulo state, which represent a region of relative industrial consolidation and expansion respectively (Figure 1). Interviews were held across the region with salaried and seasonally contracted sugar cane cutters, outsourced drivers of the trucks transporting raw sugar cane. Machine operators, auxiliary, and maintenance staff were interviewed in three mills/distilleries. These were 
complemented with interviews with managers and representatives of companies and trade unions operating in the region. Where appropriate interviews were recorded in audio, and transcribed. In situations where recorders were not permitted (for example, within the mills), notes were made and a more detailed record of the meeting was subsequently made on the same day of interview. Former agricultural workers, now unemployed, were interviewed following public meetings or while gathering testimonies from members of the MST occupation near Assis, Sao Paulo as part of a participantobserver exercise over a ten month period in 2011-2012.

\section{The spatial fix and Brazilian ethanol production}

Both Joseph Schumpeter (1942) and David Harvey $(1989,2010)$ have furthered Marx's (1993 [1857]) writings on the necessary destruction of previously produced forces of production in order for capital to continue to accumulate and generate profits. Schumpeter utilised the term 'creative destruction' to highlight how capital averts crisis in the short term through innovations that render previous capital value and labour useless, but by means that are inherently unsustainable. His work detailed how innovation postpones capital's periodic crises over time. The geographer Harvey emphasised how capital shifts its internal contradictions around in space, redistributing risk geographically while compressing the time taken to extract, process and transport its products ('time-space compression'):

Creative destruction is embedded within the circulation of capital itself. Innovation exacerbates instability, insecurity, and in the end, becomes the prime force pushing capitalism into periodic paroxysms of crisis. [...] The struggle to maintain profitability sends capitalists racing off to explore all kinds of other possibilities. New product lines are opened up, and that means the creation of new wants and needs. Capitalists are forced to redouble their efforts to create new needs in others [...]. The result is to exacerbate insecurity and instability, as masses of capital and workers shift from one line of production to another, leaving whole sectors devastated [...]. The drive to relocate to more advantageous places (the geographical movement of both capital and labour) periodically revolutionizes the international and territorial division of labour, adding a vital geographical dimension to the insecurity. The resultant transformation in the experience of space and place is matched by revolutions in the time dimension, as capitalists strive to reduce the turnover time of their capital to "the twinkling of an eye". (HARVEY, 1989, p. 105-106). 
Hence, Harvey demonstrates how capital escapes the periodic crises of over accumulation and falling rates of profit by finding a 'spatial fix': capital must construct and control new spaces in order to function; however, over time these too are unable to return an adequate rate of profit and so capital relentlessly seeks new spaces for expansion, destroying the previously 'fixed' space (including capital assets and labour) for its functioning (2001a, p. 307; $2001 b$, p. 24-25). The contradictions inherent within the process of accumulation are exemplified by the relentless requirement to produce ever more and ever faster. This may result in expensive technologies or structures becoming obsolete before they've rendered a return on investment. Profits fall, debts accumulate and, as a result, further territorial control, competitive advantage and market share are desperately sought to restore profits and competitiveness. The 'fix', therefore, is never a permanent solution but a temporary escape from the internal contradictions of capital (HARVEY, 1981, p. 307). These inherent contradictions ensure the eventual reproduction of instability as capital seeks to avert crises.

Harvey outlines four key strategies in which capital postpones these episodic crises:1) new externalmarketsare createdacrossgeographic space ;2) timeis"bought" by investing surplus capitalin long-term projects such astraining, infrastructure, research and communicationthat overcome spatial barriers and generateprofits in the future; 3) by improvingexistingmachinery, technologyand creating newproductionfacilities, and 4) expanding thepopulationavailableto workthrough theseparation ofworkers from the meansof production(HARVEY, 2001a, p. 304-6; 2003). These strategies are considered in turn in relation to the $21^{\text {st }}$ century internationalisation of Brazil's sugar and ethanol sector.

\section{Towards ethanol as a global commodity: creating a market for biofuels}

\section{European Union and transport}

The Kyoto protocol of 2002 set global targets for carbon emissions in ordertocounter global warming. This environmental policy was coupled with geopolitical and economic concerns that an over reliance on depleted fossil fuels, and oil in particular, was a perilous strategy.Following the subsequent Kyoto Agreement of 2005, 27 of the European Union member states are committed to a 20 per cent reduction in greenhouse gas emissions, a 20 per cent increased efficiency and energy use and a 20 per cent rise in the share of renewable resources to Europe's energy needs by 2020 (EC, 2009). 
Despite a broad consensus within the science community that tackling global warming and natural resource depletion required a reduction in consumption levels, it became clear that EU policy was heavily influenced by powerful lobbies that involve leading agricultural, energy, transport companies along with government stakeholders that seek tolower carbon emissions without compromising production targets. In fact carbon emissions rose by $40 \%$ in the $21^{\text {st }}$ century and in the EU, where transport counts for $30 \%$ of energy use and is $98 \%$ reliant on fossil fuels, $90 \%$ of increase in carbon emission was from transport causing several members states to fail on their Kyoto targets to date (FRANCO et al.,2010). Against these figures the key lobby in the European Union argued for a replacement of oil based petroleum with biofuels (BIOFRAC, 2006; EBFTP, 2008; see FRANCO et al., 2010 for discussion). Liquid biofuels are favoured by major companies in the energy and transport sectors. They require little change to existing energy infrastructure while the cost for converting private vehicles to 'flexi-fuel' engines that can run on either petrol or ethanol have been reduced to a minimum. With predictions that biofuels may account for up to $25 \%$ of fuel use by vehicles in the European Union by 2030 (BIOFRAC, 2006) it is clear, however, that Europe has neither the land nor climate to provide the required biomass. This has triggered a turn to the global south, and Brazil in particular, as it is the first country to boast an integrated fuel matrix.

\section{Brazilian ethanol and capital's spatial fix}

This large scale incursion of EU, US and Asian capital onto Brazilian soil cannot be disassociated from the global financial crisis that impacted on the industry after 2008. When the US investment bank Lehmann Brothers collapsed, $\$ 635$ billion disappeared triggering a crisis that quickly spread. For example, Ireland's government invested $\$ 574$ billion in an attempt to save the banks, the UK some $\$ 875$ billion. The Brazilian sugar and ethanol industry was not immune. As Mendonça et al. (2013) demonstratethe debts of leading corporations that had speculated on the international financial markets escalated in the wake of the crisis. The sudden restriction of credit and government loans mean that those companies without access to credit to redistribute existing debts and make necessary investments to competitive folded. Forty-one companies have ceased operations since 2008, with 30 of these folding in just two years (2011 and 2012), costing an estimated 13000 direct and 32000 indirect jobs (FOLHA DE S. PAULO, 2012).

In 2009 the Brazilian Sugarcane Industry Association (UNICA), controlling $50 \%$ of Brazil's ethanol and $60 \%$ of sugar production, received no less than 162 representatives from 83 countries in 2009interested in biofuels 
(CHADDAD, 2010). Rejuvenated by President Lula da Silva's promotion of flexi fuel production in 2003, the industry overcame the crisis of 1998-2000 with the help of some $\$ 28.2$ billion in government grants and loans. It almost doubled the land devoted to sugar cane, increased the production of sugar from 258 to 625 million tonnes and ethanol from 11 billion to 28 billion litresbetween 2000 and 2011.Although much of the development was markedly home grown, with public-private partnerships advancing technology and infrastructure, there was a flow of international capital into the sector. Leading global firms in energy, food, transport and logistics were enticed by favourable interest rates, the dismantling of trade barriers, the rising price for biofuels and predictions that $27 \%$ of the world's total transport fuel by 2050 could be sourced from biomass (IEA, 2011). Between 2000 and 2010 there were more ninety nine mergers or acquisitions. Amidst volatility in the US and European banking sector, foreign investment in Brazilian sugar and ethanol production tripled in the three years following the financial crisis (2008-2011) and now four of the leading five companies producing sugar and ethanol in Brazil are more than $50 \%$ controlled by foreign capital (SCARAMUZZO, 2009). This has transformed the rate and scale of production with a tendency towards monopolisationby leaders such as Raizen and Odebrecht Agroindustrial in our region of study to which we now turn.

\section{Territorial expansion}

The alliance of oil giant Royal Dutch Shell with Brazil's Cosan to establish Raizen in 2010 was the largest of the industry's $21^{\text {st }}$ century spate of mergers and takeovers. The $\$ 12$ billion merger that promised to 'turn ethanol into a global commodity' (COSAN, 2010) followed from Cosan's expanding portfolio of mills, its investment into transport, logistics, port terminals and energy infrastructure that included the purchase of the Exxon distribution network and also absorbed its debts of over $\$ 200$ billion (at the time of the merger). The mergerincreasedexport capacity, accelerated production and eased access into western states of Mato Grosso do Sul and northwards into the cerrado region of Goias. With the takeover of the Nova America distilleries of Benálcool, Tarumã, Paraguaçu Paulista and Maracaí in 2009 (See Figure 1) Cosan'sprocessing capacity rose from 44 to 60 million tonnes, producing 2 billion litres of ethanol per year (COSAN, 2010), while the former owners entered into a partnership to supply raw sugar to the sites. This strategy continued under the Raizen venture, whereby the responsibility for the supply of raw sugarcane (and the associated labour) in western Sao Paulo, Mato Grosso do Sul and Goias is pushed onto the contracted providers while Raizen maintains direct control of the industrial units. By 2015, NovAmerica seek to 
supply 10 million tonnes of sugar cane from around 120,000 hectares to Cosan units.

In this most recent phase of industrial expansion, four of the five firms that arrived in the Pontal do Paranapanema were corporate groups as opposed to indigenous companies set up by large landowners under the government sponsored Proalcool programme that had first appeared in the 1980s. The Brazilian based multinational Odebrecht entered a joint venture with the Japanese firm Sojitz and arrived in the region as Odebrecht ETH (now Odebrecht Agroindustrial) in 2006, rapidly acquiring struggling mills and incorporating local producers into its growing reach.

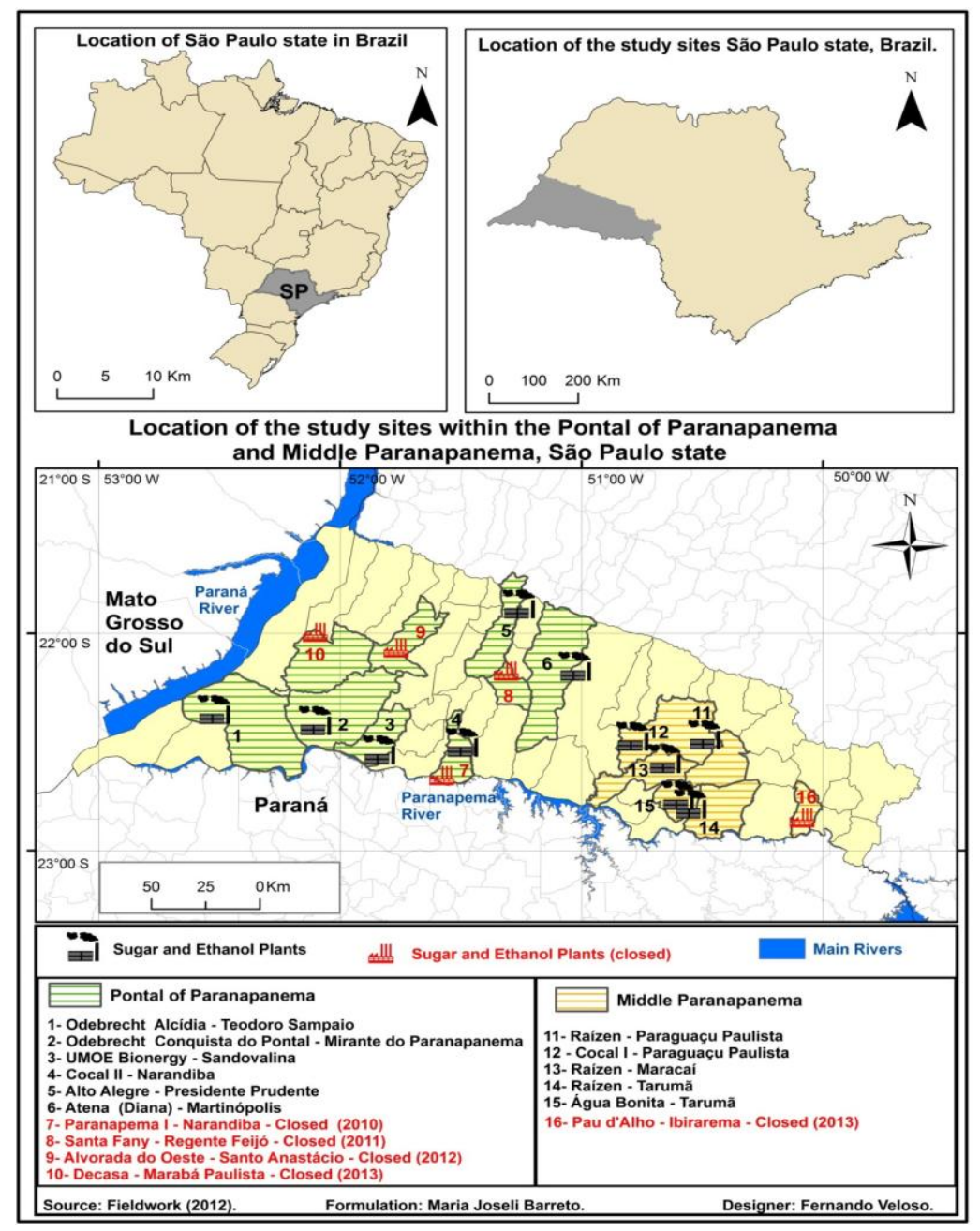

Figure 1: Map of the locations of the distilleries included in the study. 
The subordination of land under these new hands has increased the area of sugar cane in Pontal from 75 million to some 330 million hectares 20002010. A spokesperson for Odebrecht predicted a further US\$8 billion investment in its eight plants andwas seeking to control 100000 hectares in the Pontal region alone, as the company moved in and took over the distillery and associated land. The expansion of these companies points to a relentless drive to increase market share that hinges on the ability to redistribute existing debts, control increasing areas of land either by purchase, rent or contracting providers and make investments intechnology. While presenting to international arenas the development opportunities the companies bring to rural areas, there is another side to their success that is revealed by those who seek a living in these spaces.

\section{Creative destruction}

[The...] process of industrial mutation [...] that incessantly revolutionizes the economic structure from within, incessantly destroying the old one, incessantly creating a new one. This process of Creative Destruction is the essential fact about capitalism. It is what capitalism consists in and what every capitalist concern has got to live in(SCHUMPETER, 1942, p. 8283).

The corporate partnership of Raizen with NovAmerica exacerbated problems for the family owned Pau d'Alho plant in Ibirarema. Drawing sugar from 8,700 hectares the plant was beset by administrative problems that were only exacerbated by the financial crisis and competition from neighbouring mills. NovAmerica, that was drawing 500,000 tonnes of sugar cane from over 6000 hectares of land rented in the municipality had considered a takeover but was set back by its own financial difficulties. When the plant closed, unannounced, in January 2012 it did so with a debt of US\$26 million in unpaid wages and social security entitlements. Almost 2000 workers lost their jobs and the town of Ibiraremadeclared a state of emergency. Up to 1000 workers in the town of only 7200 inhabitants had been employed directly or indirectly by the plant. Local papers carried news of businesses suffering a 40 per cent decrease in sales and 80 families had left the town(VOZ DA TERRA, 2013).

At 7 a.m. on a Wednesday morning on the week before Christmas, twelve workers who had previously lost their jobs at the Pau d'Alho plant were among those who had stepped off a full bus and into a neighbouring mill in Paraguacu Paulista. A worker in his twenties shook his head: 
I worked at Pau d'Alho for seven months and then it closed. I'm still waiting for my pay. We blocked the roads. The TV cameras came. We were told that, for sure now we would get our wages. Nothing. I got a job on the roads, an outsourced job. The work was interrupted and we were let go. We didn't receive our last wage. Now this.

$\mathrm{He}$, like the others, sought work in this distillery in the previous May. On this day in December, the factory was not functioning. Nobody knew where the manager had gone. They had not received wages since early November. Some had returned to the cassava fields by day and returned to the factory for night shifts to offset their loss of wages.

In the Pontal, only two of the companies that had established mills under the Proalcool programme still existed at the time of the second phase of industrial expansion after 2004. A spokesperson for one of these described the impact as multinationals of Odebrecht Agroindustrial and UMOE BioEnergy, a Norwegian firm, arrived and began incorporating land and disused mills as part of the territorial and market expansion. The increase in land rents made itimpossible forAlvorada do Oeste to meet the rental payment for the 7000 hectares it required to supply adequate amounts of raw sugarcane (it sourced a further 2000 hectares from local farmers) and still make the technical investments it required in order to compete with the large firms. Following the further squeeze on credit after the 2008 financial crisis, production fell below capacity, less than 600000 tonnes, in 2011 and in 2012 the company ceased activity.

A similar fate had befallen workers at the Santa Fany plant in the municipality of Regent Feijó. Five months after the closure, a few workers had found informal employment but a public meeting in the city hall was filled with frustrated and unemployed citizenss, still awaiting unpaid wages.After the meeting Carlos (aged 58) who had worked in the Santa Fany mill as a mechanic, repairing the fleet of tractors, trucks and harvesters remonstrated:

It has always been tricky to work in the company, due to delay in payment of wages, of vacation pay, 13th wages.[ ... ] But in that year ( 2010 ) the situation worsened once, all were discharged. [ ... ] They paid some workers and left others without receiving anything, paying others with bad checks. There are workers who received the last paycheck in September 2010, the company closed in January 2011, we are in June now!

For Carlos and his co-workers unemployment was an untenable situation, but one which suppresses wages in these rural towns targeted by the multinationals for labour.These accounts point to the volatility of the sugar and 
ethanol sector that is increasingly dominated by export orientated multinationals and the risk that the concentration of land, employment, financial and political power into large scale monoculture holds for small, rural municipalities. Just as striking, however, is the impact on rural livelihoodsin municipalities where successful mills in the hands of multinationals are expanding their capacity.

By 2011 the plant at Maracai that Raizen assumed in 2010 was receiving 1.7 million tons of cane sugar, producing130 million tons of sugar and 63 million litres of ethanol and became the world's first mill to receive the seal of the Better Sugar Initiative, increasing its export potential. This UK based certificate, subsequently endorsed by the European Union provides a guarantee of quality standards on environmental and, to a lesser extent, social grounds. In recent presentation to the International Energy Agency (2011), Raizen pointed to the environmental and social record of the plant and emphasised the development opportunities the company brings to rural areas. The small and still relatively poor municipality of Maracai, however, had 18000 inhabitants in the late 1980s. Sugar and, to a lesser extent, soya began to dominate agriculture in the area ever since NovAmerica took over the distillery in 1957. Cosan took it over in 2009before merging with Shell to form Raizen. Today the population has fallen by around 5,000 to 13,000 inhabitants. According to those involved in the industry over the last three decades, two factors oversaw this exodus; firstly, monoculture replaced the more diverse and small farming agriculture on which the town had been built; secondly, machines began to replace the manual workers in the fields of soya and sugar and automation within the factories negated further job creation.

\section{Mechanisation and sugar cane cutters}

Joao (aged 57) spoke after a meeting of the landless people's movement beside the rail track leading out of Assis. Hedrew on a rolled cigarette and recalled the days when opportunities for agricultural work were more abundant and varied, and when the terra roche, the rich, red soil of this river basin had provided incomes from maize and cattle, coffee and cotton. Life had not been easy, but the seven seasons he and his wife had spent cutting sugar canein Maracai and Trauma were just part of various jobs that had sustained them and many relatives. "My life has been like that", he stated, "going from cattle to coffee, sugar, here, there, around Assis , a few seasons in Parana, before the sugarcane took over". His wife Elena had been the first to be dismissed from the fields as women were relegated to planting and then collecting the cane that had fallen from trucks, then the older workers like Joao started to be replaced by younger workers. 
Checking that an elderly member of the camp who had taken a stroke a few nights previous is taking the correct medication,Elena, one of the camp's co-ordinators speaks softly and firmly,

In the periphery [of the city] it isn't safe, the unemployment, the drugs are a problem, it's dangerous; people with hunger, going hungry, it's a real problem. That's why we fight for the land. We have a right to it, we know how to work it, grow our own food. We fight for this. But no one wants to help.

They demanded seven hectares of land each; the minimum for family survival. But so far the government institution for agrarian reform, INCRA, had offered nothing. They had been given ten days to leave their occupation by the courts and police, after objections from ALL, the transport logistics company (Cosan have a 10\% share in the firm) who own the adjacent rail tracks.The children are lifted from the tracks when an oncoming cargo train of soya charges by. Fourteen months later the camp dwellers, faced with little prospect of gaining increasingly expensive land in this area of Sao Paulo, disbanded. Eight families had travelled to join a larger camp in Marabáin Pontal to which they had been invited by the movement, but by Christmas 2013 there had been no progress with the authorities. A co-ordinator who had been among them returned to Assis. His grandfather had worked with cattle, as had he for a short time in Parana. He had sought to get some land so he could bring his children back and live with him there.

Hearrived to talk to us by bicycle as he had no longer the money to fuel his car. His partner was seeking cleaning work in the town and he was hoping to pick up any kind of work he could. Many of the 80-100 families that had been involved in the occupation returned to the peripheries of the small rural towns. They included former sugar cane cutters from Paraguacu, Assis and Florinea that had been among the ranks of unemployed forming this land occupation, now trying to access the family assistance packages that many of those expelled from the closed distilleries were also relying on across the region.As the following section illustrates, the prospect of unemployment weighed heavily on the shoulders of remaining sugar cane cutters of Assis, Taruma and Maracai and Pontal and incentivised the acceptance of precarious work by drivers in the industry.

\section{Sugar cane cutters}

Raizen recently affirmed to the International Energy Agency: 
As a large company, Raizen contributes substantially to social sustainability. There is less reliance on manual labour - in the harvest of 2011/2012 more than $70 \%$ of the canes will be harvested mechanically (IEA 2011a, p. 9).

Its implicit equation that the company draws between social unsustainability and manual labour is recognition of the degrading conditions workers have endured throughout the industry's history and an attempt to set aside Cosan's addition to the dirty list of companies utilising slave like labour in 2009. In the 2006-2007 harvest, only $18.6 \%$ of the sugarcane in Brazil was mechanized. In 2008-2010 the figure rose to 45.3\%. By 2015 mechanisation in Sao Paulo state may be complete, ending jobs in their tens of thousands. As a result of this Raizen,despite its global expansion, directly employed around 5,000 less workers across its 24 plants in 2013 than it did in 2012 (RAIZEN, 2013). The statement above, therefore, points to the paradox in work quality in security within the modern industry to which we now turn.

The introduction of harvesting machines have been the way that large producers with economies of scale have reduced labour costs while disappearing the 'problem' of slave like labour that has been unpopular with consumers. One harvesting machine replaces 80-100 workers and their introduction in the Middle Paranapanema region by NovAmerica in the 1990s began the annual cull of cane cutters. There had been 2300 cane cutters from Assis town in NovAmerica plantations in Maracai and Taruma in 2003. Last year there were 230. Next year there will be none.The Association of the Brazilian sugar and ethanol industry (UNICA) has convinced the ILO (2012) and UNEP among others that re-training programmes, such as those publicised also by Raizen (2013), are effective in securing employment for many of those being replaced by machines. A recent survey of 40,000 sugar cane cutters made redundant between 2007 and 2011 in Sao Paulo state, however, found that only 7 per cent had gained new jobs in the industry (BACCARIN,2011).

Pedro, (aged 47) was in one of only two teams of sugar cane cutters in the Agua Bonito plant of Taruma in the 2011/2012 season. The previous year there had been 14 teams. He knew only two former cane cutters who had secured work elsewhere within the industry. Many we spoke with had begun the courses but were unable to finish, while others point out that the fees for the course were unaffordable, yet the employers expect the workers to cover these costs. A result of this, a local rural trade unionist stated, has been an increasing pressure on remaining workers to retain employment by increasing productivity as the owners 'choose the best, the strongest' at the end of each season for the following year. 
According to him the development of the industry toward export had brought fresh scrutiny to the region around Taruma, Paraguacu and Maracai. Third party contracting of workers had been phased out, inadequate hostels for migrant workers closed as the Ministry of Labour had been active in penalising abuses in an industry seeking to attract foreign investment and find international markets for produce. Yet wages remained low. Pay by production endures. One worker, Junior, recalled hospitalisation after collapsing in the fields in 2009 in Marcai and highlighted the intensity of work that it is widely thought to have contributed to the deaths of 14 workers in Sao Paulo in just two seasons 2005/6 and 2006/7.

For migrant workers, however, the phasing out of 'gatos', the third party contractors, infamous for extracting profit at the expense of migrant workers and who have been involved in most cases of slave like labour found in the cane fields of Sao Paulo, did not prevent overwork. Miguel had been among 350 workers brought from Minas Gerais by an agent of the Atena plantation in Martinópolis for the 2011/12 season. He was paid just $\mathrm{R} \$ 0.14$ per meter of sugar cane cut and routinely increased his working day to ten hours (from eight) in order to secure enough money to cover the family's expenses and afford their journey back to Minas in October. It is understood in the region that to be kept on as a cane cutter you must cut at least 10 tonnes per day (the rate was around 5-8 tonnes in the 1980s). The pressure to retain the job and compensate for the low pay mean that workers we spoke to were managing to cut up to 16 tonnes per day.

\section{Outsourced truck drivers}

As mechanisation gradually replaces sugar cane cutters, the loading and transport of sugar cane have been identified as areas for further cost savings by the logistical companies proliferating in the industry. This, in the discourse of the industry, creates 'additional' job opportunities in the rural areas targeted by sugar and ethanol companies. A specialisation of tasks, cost reductions, acceleration of production and transport and constant renewal of technology have characterised the 'modernisation' of the industry (SCHEIDL and SIMON, 2012). Raizen have separated out the agricultural and industrial sections of production, taking responsibility for the latter but pushing the responsibility for the supply and quality of raw sugar cane to contracted providers. Odebrecht Agroindustrial outsourced all activities beyond its primary processing operations within the mills in Pontal. In the Pontal region we found that often contracts between suppliers to the sugar and ethanol mills were struck between large landowners producing sugar cane and third and even fourth party transport companies, tasked with delivering sugar cane to mills. 
Out of sight of state regulation or trade union involvement these agreements were, arguably, creating some of the country's most hazardous working conditions. In 2011 and 2012, five drivers of the municipalities of Pontal of Paranapanema lost their lives in traffic accidents on roads. Daily trips and targets for drivers are set by employers, but require flexibility on behalf of the workers who are anxious to secure employment and co-operate with almost impossible targets. Jose (aged 36), for example, was employed by a small company providing services to plantations across the region. He was expected to make three trips daily, but where the cutting 'front' of the plantation was some $75 \mathrm{~km}$ from the mill, he had to skip his lunch hour and lengthen the working day to do so. Technological advances, logistical organisation and worker flexibility have increased distances between the mills and land being taken into sugar cultivation.

As is so often the case, 'lean' organisation strategies transfer the flexibility and stress onto labour (APPELBAUM 2008; RAWORTH AND KIDDER,2009: 171). Given the distances travelled and the poor regulation of this outsourced work, those working a twelve hours shift were away from home 15 hours a day, while those who were employed on 24 hour shifts were returning to work only after 27 hours rest. These testimonies illustrate some of the particular social challenges in an industry that belie claims of environmental and social responsibility.

\section{Socially responsible work}

Sustainability is a concept that has become as increasingly vague as it is popular and has been less developed in the social sphere than it has in relation to economics and the environment. There is no accepted definition of social sustainability (JACKSON,2009). While ILO and UNEP are among those who have highlighted opportunities for employment within the green economy, their approach reflects a more general lack of clarity onwhat kind of work we wish to develop, how we may begin to make that happen, or the type of social project that can allow people to flourish and meet their material needs.

It is within this vacuum that corporations have promoted an idea of social responsibility in line with the ideology of the free market, while also leaning heavily on state support for their territorial, technological and market advances. At present the large scale monocultural production of ethanol is favoured by Brazilian political and economic elites and there is, as Harvey (2001a) puts it, a 'structural coherence' detected between the international, state and regional political and economic forces that transform landscapes and concentrate land and wealth. Although the World Trade Organisation prioritises the dismantling of barriers that would interrupt, the 'harmonious 
relationship between trade and environment regimes' (WTO,2014), it is obvious that Brazilian, EU and US corporations promoting green energy continue rely on state support to facilitate biofuel expansion.

New green technologies avail of generous government grants and credit that are justified at international policy level on the grounds of their cost and contribution to combating global warming. In stark contrast, more rigid social criteria proposed at an international level (EU Renewable Energy Directive) that would, for example, link fair pay for workers and local community land rights to export agreements was resisted, partly on the grounds that it would contravene free trade rules (FRANCO et al.,2010). Similarly the World Bank has expressed approval of land redistribution in Brazil, but only if it not 'interfere with investment' (WORLD BANK 1997; see LAMBAIS, 2008 for discussion). While the government continues to offer credit (including a recent $\$ 1$ billion credit line for secondary biofuel technology development) to large corporations in our region of study it had completely stalled agrarian reform in Sao Paulo state.

Under the prevailing market driven logic the large scale layoff of manual cane cuttersis marketed as responsible progress (IEA, 2011). Labour improvements in specific sites of production are highlighted while the related dislocation and displacement of work opportunities are sidestepped. The government has provided family assistance packages such as Bolsa Familia to newly created groups of poor and dispossessed, but by September of 2013 had not redistributed one hectare to the landless of the country in that year.

As Jackson (2009, p. 9) writing on the theme of sustainable development, observes:

Physical and mental health matter... Relationships, meaningful employment, and the ability to participate in the life of society appear to be important almost everywhere. People suffer physically and mentally when these things are absent. Society itself is threatened when they decline.

$[\ldots]$ The challenge for society is to create the conditions in which these basic entitlements (for a decent life) are possible. This is likely to require a closer attention to the social, psychological and material conditions of living - for example, to people's psychological wellbeing and to the resilience of communities than is familiar in free market societies.

From the testimonies presented above we have identified how modernisation has led to large scale labour exclusion for rural workers, a limiting of opportunities for rural employment and livelihoods, and an intensification of work as a result of mechanisation and outsourcing that reached fatal levels in Sao Paulo. The Ministry of Labour of Brazil, a country 
with firm labour laws, highlights that conditions persist in which work is certainly not sustainable; workers are unable to reproduce their work effort, their labour power, without detriment to themselves. A worker is held in conditions 'analogous to slavery' if he or she is 'subjected to forced labor or an exhaustive routine, to degrading work conditions or has mobility restricted by any means due to debt to the employer or agent' (MINISTERIO DO TRABALHO E EMPREGO, 2003). Under the Ministry's criteria, half of the 67000 workers freed annually from conditionsBrazil between 2005 and 2009 were internal migrant workers working in the sugarcane industry (REPORTER BRASIL, 2011).

Along with Brazil's corporate and state determination to lead production and export of 'clean' energy, there has been a publicity drive to improve the industry's image (CHADDAD, 2010). It is notable that it was on environmental rather than social grounds that the burning of sugar cane has been phased out in Sao Paulo, ending jobs in tens of thousands (burning is required before manual cutting). At the behest of the government, however, UNICA signed in June 2009 the voluntary National Commitment for the Improvement of Labour Conditions (NLC) in Sugarcane Production with two trade union Federations (FERAESP and CONTAG) that undertook, among other commitments, to 'phase out' third party contacting of manual workers.

From the outset the ability of avoluntary initiative to bring broad guarantees across the industry rather than form niches of good (better) practice was questioned; as was the effectiveness of the audits carried out by private firms that grant the seal of approval to signatories of the NLC. President Dilma Rouseff, however, gave her endorsement by personally presenting certificates to 169 companies that had been auditedby 2012. UNICA publicised the endorsements widely. By the end of the year, however, 60 of these companies were being investigated through the courts for serious labour violations that included the exhaustion, illegal sub-contracting and degrading treatment of workers. In Goias State, home to the greatest recent expansion of sugarcane, the 39 workers freed from slave-like conditions in 2011 had been found working in the mechanized cutting of cane. They had been subjected to 27-hour working periods without a break and the two workers involved in a serious accident had each been working in excess of 20 hours (REPÓRTER BRASIL, 2011).

In São Paulo, 26 of the 85 certified companies were involved in labour court actions for failing to provide their workers with protective equipment, toilet, eating or rest facilities, and for continuing to use third-party contractorsto hire workers. Amongst these was Cosan/Raizen Energia, the largest plant in the country, which faced 35 violations and had one conviction 
on appeal relating to inadequate provision of rest for workers, inadequate breaks and for dismissing workers in the mechanized harvesting sector only to rehirethem through an agency the following day at 63 per cent of the wages (JOURNAL OF ARARAQUARA, 2012). In neighbouring Paraná state migrant workers from Bahia, Pernambuco and Maranhão constituted the second-largest 'rescue' from slave-like conditions in the country, just months after the audit had approved National Commitment membership for their employer, the three time President of the Associationof Bioenergy Producersof Paraná (REPÓRTER BRASIL, 2013). The agreement has been discontinued, a trade union spokesperson accusing the industry of using workers and unions to sell ethanol abroad (NOVOCANA,2013).

The account points to a considerable gap between the claims of social responsibility made by industry publicists and the contemporary situation facing labour in the sites of sugar and ethanol production. It gives weight to Harvey's recent argument (2012) that we cannot develop responsible approaches either to nature or to work without a determined shift in the social relations that connect what we do to each other to how we interact with the natural environment. Under the current model of large scale plantation-fed ethanol production on Brazilian soil, industry consultants predict an expansion of 3.1 million hectares in sugarcane, an annual output of one billion tonnes of raw sugar that requiresa further foreign investment of R $\$ 44$ billion by 2020 (MOREIRA, 2011). This expansion will undoubtedly bring employment to many semi-skilled and skilled workers in specific sites, cautioning against overly simplistic theories of a downward spiral of work conditions, pay and quality (Silver 2003). Yet, aside from the considerable environmental implications of these projections, UNICA predicts that of the 330 plants in the central south region, some sixty mills will soon go out of business or change ownership (ESTADO DO S.PAULO, 2013) leading to further unemployment and social problems in small rural towns also dealing with the imminent loss of around 150,000 sugar cane cutters in Sao Paulo state alone (CHADDAD, 2010). As multinationals move west and north into Mato Grosso do Sul and the cerrado region of Goias, energising sugar and ethanol production towards foreign markets, it is reasonable to anticipate that social costs that we have observed in Sao Paulo state will be reproducedand borne much more locally in these spaces. On the evidence of workers' testimonies carried here, a more determined protection of existing worker's rights and livelihoods is necessary, while responsible employment that provides for socially committed, secure and fulfilling work is something still to be constructed. 


\section{Conclusion}

This paper has framed the internationalisation of Brazil's sugar and ethanol industry within capital's continual postponement of crisis through innovation and territorial expansion. Harvey's theoretical work on the spatial fix demonstrates that capital constructs its own space in order to function, but must destroy that space in the future to make way for new opportunities for accumulation, devaluing capital stock and annihilating labour in the process. We have outlined some of the implications of large scale sugar and ethanol production for labour exclusion and displacement, security and precarity, and shown limitations to creating alternative rural livelihoods in the western part of Sao Paulo state.

The experiences of four categories of workers were presented: those recently made redundant from closed distilleries, sugar cane cutters who have been replaced by machinery, salaried and seasonally contracted cane cutters who face an intensification of work, and outsourced drivers carrying out, arguably, the most precarious work in the sector. Their testimonies, along with the poor labour record for the industry in general despite a national voluntary agreement raise serious questions of corporate leaders' claims of social responsibility. Specific sites of improved employment practices were observed, but these emerge against a backdrop of enhanced competition and instability that is leading to further closures. The prevailing market orientated model of large scale monoculture and mechanisation replaces rural work and restricts the possibilities of familial agriculture sought after by the landless occupations. The drive towards the international commodification of ethanolby leading multinationals involves an increasing reliance on international finance to redistribute existing debts and continue expansion at the expense of smaller firms. The instability that we observe in the contemporary sugar and ethanol sector in Brazil, we conclude, is inherent in advances by capital across space, and has large implications for work security and quality in the new areas of territorial expansion.

\section{References}

APPELBAUM, R.P. Giant Transnational contractors in East Asia: emergent trends in global supply chains. Competition and Change, 12 (1), p. 69-87, 2008.

BACCARIN, J. G. Boletim - Ocupação formal no setor sucroalcooleiro em São Paulo, available at www.fcav.unesp.br/baccarin, 2011 (accessed 5 May 2013). 
BIOFRAC. Biofuels in the European Union: a vision for 2030 and beyond. Final report of theBiofuels Research Advisory Council, 2006.

CHADDAD, F. R. Challenges to Deliver Sustainability in the Brazilian Sugarcane Industry', International Food and Agribusiness Management Review,13 (4): 173-192, 2010.

COSAN GROUP. Annual Report, available at www.cosan.com.br, 2010 (accessed June 2012).

EBFTP. European Biofuels Technology Platform: Strategic research agenda \& strategy deployment. CPL Press. Available from:

http://www.biofuelstp.eu/srasdd/080111_sra_sdd_web_res.pdf , 2008 (Accessed 12 July 2013).

EC. Directive 2009/28/EC of the European Parliament and of the Council of 23 April 2009 on the promotion of the use of energy from renewable sources and amending and subsequently repealing Directives 2001/77/EC and 2003/30/EC Renewable Energy Directive, O.J. L 140: 16-62, 5 June, 2009.

ESTADO DO S. PAULO. 'Crise leva quase $20 \%$ das usinas de cana do CentroSul a fechar ou mudar de dono' 18 De Março 2014, available athttp://www.estadao.com.br/noticias/impresso,crise-leva-quase-20-das-usinasde-cana-do-centro-sul-a-fechar-ou-mudar-de-dono,998219,0.htm (accessed 24 March 2014).

FOLHA DE S. PAULO. With the crisis, country loses 30 distilleries in the past year, 21 July 2012, available at:

http://www1.folha.uol.com.br/cotidiano/ribeiraopreto/1123526-com-crise-paisperde-30-usinas-de-cana-de-acucar-desde-o-ano-passado.shtml (accessed 22 March 2013).

FRANCO J.; LEVIDOW, L.; FIG, D.; GOLDFARB, L.; M HÖNICKE and MENDONÇA, M. L. Assumptions in the European Union biofuels policy: frictions with experiences in Germany, Brazil and Mozambique, Journal of Peasant Studies, 37 (4), 661- 698, 2010.

HARVEY, D.The spatial fix: Hegel, von Thunen and Marx. Antipode 13, 3: 1$12,1981$.

HARVEY, D. The Condition of Postmodernity. Cambridge, MA and Oxford: Blackwell, 1989,pp. 378.

HARVEY, D. Spaces of Capital: Towards a Critical Geography. Edinburgh: Edinburgh University Press and New York: Routledge, 2001a, pp. 429. 
HARVEY, D. Globalization and the spatial fi x. Geographische Revue 2: 2330, $2001 b$.

HARVEY, D. The New Imperialism. Oxford: Oxford University Press, 2003, pp. 253.

HARVEY, D. The Enigma of Capital and the Crises of Capitalism. London: Profile Books,2010,pp. 296.

HARVEY, D.Video. 'Social movements rather than sustainability' ,14 September 2012 Available athttp://whitherwaste.wordpress.com/2012/09/14/david-harvey-socialmovements-over-sustainability/ (accessed 26 February 2013).

INTERNATIONAL ENERGY AGENCY. Future Biomass-based Transport Fuels: Summary and Conclusions from the IEA Bioenergy ExCo67Workshop, 2011a. Available at http://www.ieabioenergy.com/wpcontent/uploads/2013/10/ExCo67-Future-Biomass-based-Transport-Fuelssummary-and-conclusions.pdf(accessed 2 November 2012)

INTERNATIONAL ENERGY AGENCY. Technology Roadmap: biofuels for transport. OECD/IEA, 2011b. Available at

www.iea.org/publications/freepublications/.../biofuels_roadmap.pdf, (accessed 7 November 2013)

INTERNATIONAL LABOUR ORGANISATION. 'Decent work agenda', 2012a. Available at http://www.ilo.org/global/about-the-ilo/decent-workagenda/lang-en/index.htm (accessed 2 November 2013).

INTERNATIONAL LABOUR ORGANISATION and UNITED NATIONS ENVIRONMENTAL PROGRAMME. Working towards sustainable development : opportunities for decent work and social inclusion in a green economy, Geneva: ILO, 2012 b.

JACKSON, T. Prosperity without growth? A transition to a sustainable economy. Report for the Sustainable Development Commission,2009, pp. 136. JORNAL DE ARARAQUARA, Sao Paulo. Raízen (antiga Cosan) é Processada pelo MPT, 21 April 2012. Available at

www.brasilagro.com.br/index.php?noticias/detalhes/3/43091 (accessed on July 6, 2013)

LAMBAIS, G.B.R. Land Reform in Brazil: The Arrival of the Market Model. Paper delivered at The Institute of Latin American Studies Student Association Conference, University of Texas in February, 2008. 
MARX, K (1993) [1857]. Grundrisse: Foundations of the Critique of Political Economy. Nicolaus, Martin (trans. 1973). Harmondsworth, UK: Penguin. pp. 750.

MENDONÇA, M.L., PITTA, F.T. and XAVIER, C.V. The Sugarcane Industry and the Global Economic Crisis. Transnational Institute (TNI), 2013.

MINISTERIO DO TRABALHO E EMPREGO. Plano Nacional para Erradicação do Trabalho Escravo, 2003. Available athttp://portal.mte.gov.br/trab_escravo/plano-nacional-para-erradicacao-dotrabalho-escravo.htm, accessed 24 November 2013

MOREIRA, C. Limite de venda de terras a estrangeiro barrou entrada de US\$ 15 bi no País. Agência Estado. São Paulo, 18 April, 2011. Available at http://economia.estadao.com.br/noticias/neg\%C3\%B3cios,limite-de-venda-deterras-a-estrangeiro-barrou-entrada-de-us-15-bi-no-pais,63309,0.htm. (accessed on 5 September, 2013).

NOVOCANA. Repleto de problemas, "compromisso nacional" para melhorar as condições de trabalho da cana perde validade,22 July 2013. Available at www.novacana.com/n/cana/trabalhadores/problemas-compromisso-nacionalcondicoes-trabalho-cana-220713/\# (accessed 24 July 2013).

RAIZEN. Annual Report 2012. Available at www.raizen.com (accessed 15 March 2013)

RAWORTH, K, and KIDDER, T. Mimicking "Lean" in Global Value Chains'. In J. Blair (Ed.) Frontiers of Commodity Chain Research. California: Stanford, 2009, Chapter 8.

REPÓRTER BRASIL. O Etanol Brasileiro no Mundo - Os impactos

Socioambientais Causados por Usinas Exportadoras, 2011.Available at http://www.reporterbrasil.org.br/documentos/Canafinal_2011.pdf (accessed 2 May 2012).

REPÓRTER BRASIL. Latest Notices, 2013. Available at http://www.reporterbrasil.org.br (accessed 22 July 2013).

SCARAMUZZO, M.Estrangeiros avançam nos canaviais', Valor Econômico, 30 June 2009.

SCHEIDL. H. A. and A.T. SIMON. Avaliação do processo de terceirização do corte mecanizado, carregamento e transporte de cana-de-açúcar'. Revista de Ciência\&Tecnologia,17 (33),103-118, 2012. Available at www.metodista.br/revistas/revistas- unimep/index.php/cienciatecnologia/issue (accessed 2 June 2012). 
SCHUMPETER, J.Capitalism, Socialism and Democracy. London: Routledge, 1994 [1942], pp. 460.

SILVER, B. Forces of Labor: Workers' Movements and Globalization since 1870 .

Cambridge University Press: New York and Cambridge, 2003, pp. 238.

UNICA (2010), Projeto-renovacao-requalifica-cortadores-de-cana, available at http://www.unica.com.br/noticia/2521848392034872045/projeto-renovacaorequalifica-cortadores-de-cana-na-regiao-de-aracatuba-a-partir-de-hoje/ (accessed 7 Setember 2012).

VOZ DE TERRA. Trabalhadores da Pau D'Alhoprotestam contra fechamento de usina e bloqueiamrodovia, 2013. Available at http://www.vozdaterra.com.br/jornal/?p=noticia\&id=1766 (accessed5 October 2013).

WORLD BANK. Economic Growth and Income Inequality: Reexamining the Links. IMF Finance and Development, 1997.

WTO (WORLD TRADE ORGANISATION). Activities of the WTO and the challenge of climate change', 2014. Available at http://www.wto.org/english/tratop_e/envir_e/climate_challenge_e.htm (accessed 6 March 2014).

\footnotetext{
Brian Garvey

Department of Human Resource Management, University of Strathclyde.

8.09 Graham Hills, 50 Richmond Street, Glasgow G1 1XP.

Email:brian.garvey@strath.ac.uk
}

Maria Joseli Barreto

Universidade Estadual Paulista Júlio de Mesquita Filho.

Faculdade de Ciências e Tecnologia, Departamento de Geografia Humana e Regional.

Rua Roberto Simonsen n 305 Centro Educacional 19060900, Presidente Prudente.

Email:joselibarreto5@yahoo.com.br

Recebido para publicação em novembro de 2013

Aprovado para publicação em dezembro de 2013 